\title{
Duquesne University African Center
}

THIs centre at Pittsburgh contributes four courses on African history and language to the Black studies curriculum of the university and is working with the Philadelphia publicschool system on the preparation of African studies materials for secondary schools. The director and members of staff serve as consultants for the school system on all African studies curricula, concentrating on the development of materials and programmes for the inner-city schools with high Black enrolments. The Center is also developing a one-year experimental course implementing the 'culture-through-language' concept. To supply the additional teachers for these new activities the Duquesne School of Education and the African Center have introduced a programme of combined studies in education and African studies leading to an M.A. in teaching.

\section{Unesco General History of Africa}

UNESCO has recently accepted recommendations of the International Scientific Committee appointed under the chairmanship of Dr. Aklilu Habte, President of the Haile Sellassie I University, to plan and edit this work under its auspices. It will be published in eight volumes. The principal edition will appear in English and French while an abridged version will be published in African languages. Each volume will consider the continent as a whole and the history of Africans interpreted as such. At least two volumes will be begun in $197 \mathrm{I}$ and the series should be complete by $197^{8}$.

The following are the proposed titles of volumes and editors named by the committee:

Vol. I. Introduction and Prehistoric Africa-Monsieur J. Ki-Zerbo (Upper Volta)

Vol. II. Ancient Africa-Dr. Gamal Mokhtar, archaeologist (UAR)

Vol. III. Africa from the 7 th to the I Ith Century-H.E. M. El Fasi, Minister of State for Cultural Affairs (Morocco)

Vol. IV. Africa from the 12 th to the 16 th Century-Mr. Djibril Tamsir Niane, Head of the Social Sciences Sector, Ministry of Scientific Research (Guinea)

Vol. V. Africa from the I6th to the I8th Century-Professor B. A. Ogot, History Department, University of Nairobi (Kenya)

Vol. VI. The Igth Century up to the r 880 s-Professor J. F. Ade Ajayi, History Department, University of Ibadan (Nigeria)

Vol. VII. Africa under Foreign Domination-Dr. A. Adu Boahen, Professor of History, University of Ghana (Ghana)

Vol. VIII. Africa since the Ethiopian War: the march towards independence-Professor Ali Mazrui, Department of Political Science, University of Uganda (Uganda)

These editors will be aided by assistant editors and a team of collaborators and authors will be nominated by the committee.

Professor J. Devisse, Faculté des Lettres, Vincennes, Paris, has been appointed rapporteur to the committee.

\section{African Religious Research Newsletter}

Ar the Dar es Salaam Conference on the Historical Study of African Religious Systems, in June 1970 , the delegates asked that a newsletter indicating current research and publication in the field should be distributed at regular intervals. The responsibility for circulating such a newsletter was taken by the African Studies Center at the University of California, Los Angeles, and the first issue, April r971, is now available. It consists of three sections. The first is a listing of current research and publication in East, Central, and Southern Africa. 